\title{
Induction of apoptosis by valinomycin: mitochondrial permeability transition causes intracellular acidification
}

Isla J. Furlong ${ }^{1}$, Casilda Lopez Mediavilla ${ }^{1}$, Rosalia Ascaso ${ }^{2}$, Abelardo Lopez Rivas ${ }^{2}$ and Mary K.L. Collins ${ }^{1,3}$

${ }^{1}$ CRC Centre for Cell and Molecular Biology, Chester Beatty Laboratories, 237 Fulham Road, London SW3 6JB, UK

2 Instituto de Parasitologia y Biomedicina CSIC, Ventanilla 11, 18001 Granada, Spain

${ }^{3}$ corresponding author: M.K.L. Collins, Department of Immunology, Windeyer Building, Cleveland Street, London W1P 6DB

tel: 44-171-380-9301; fax: 44-171-380-9301; email: mary.collins@ucl.ac.uk

Received 14.5.97; revised 9.9.97; accepted 29.9.97

Edited by M. Piacentini

\begin{abstract}
In order to determine whether disruption of mitochondrial function could trigger apoptosis in murine haematopoietic cells, we used the potassium ionophore valinomycin. Valinomycin induces apoptosis in the murine pre-B cell line BAF3, which cannot be inhibited by interleukin-3 addition or $\mathrm{BCl}-2$ over-expression. Valinomycin triggers rapid loss of mitochondrial membrane potential. This precedes cytoplasmic acidification, which leads to cysteine-active-site protease activation, DNA fragmentation and cell death. Bongkrekic acid, an inhibitor of the mitochondrial permeability transition, prevents acidification and subsequent induction of apoptosis by valinomycin.
\end{abstract}

Keywords: apoptosis; valinomycin; intracellular $\mathrm{pH}$; mitochondrial permeability transition

Abbreviations: IL-3, interleukin 3; ANT, adenine nucleotide translocator; PARP, poly (ADP-ribose) polymerase; BA, bongkrekic acid; $\mathrm{PT}$, permeability transition; TNF, tumor necrosis factor; NGF, nerve growth factor

\section{Introduction}

In many cell types, including those of the haematopoietic system, removal of essential growth factors results in apoptosis (Collins et al, 1994). The late, irreversible steps of the death programme in most cells include activation of a family of cysteine-active-site proteases (Martin and Green, 1995), which degrade a number of abundant nuclear proteins (Kaufmann et al, 1993; Song et al, 1996; Voelkel et al, 1995; Tewari et al, 1995; Casciola-Rosen et al, 1994; Lazebnik et al, 1995), and the digestion of chromatin by an endonuclease (Wyllie, 1980). Cell extracts containing activated cysteineactive-site proteases can stimulate apoptotic changes, including chromatin digestion, in isolated nuclei (Lazebnik et al, 1993; Solary et al, 1993; Martin et al, 1995; Enari et al, 1995a). Also, inhibition of cysteine-active-site protease activity in intact cells, by cell permeable peptide inhibitors (Fearnhead et al, 1995; Zhu et al, 1995; Chow et al, 1995; Jacobson et al, 1996) or expression of viral proteaseinhibitory proteins (Gagliardini et al, 1994; Tewari and Dixit, 1995; Enari et al, 1995b; Los et al, 1995; Camita et al, 1993), prevents chromatin fragmentation and delays loss of cell viability. Thus, regulation of cysteine-active-site proteases is critical for control of entry into apoptosis. These proteases are synthesised as pro-enzymes and cleaved to form the active enzyme (Nicholson et al, 1995; Tewari et al, 1995); in vitro this cleavage can be auto-catalytic or catalysed by other cysteineactive-site proteases (Xue and Horvitz, 1995; Kumar and Harvey, 1995) and in vivo there is evidence for a proteolytic cascade (Enari et al, 1996). Fas or TNF receptor-induced apoptosis is triggered by recruitment of an cysteine-active-site protease to the activated receptor (Boldin et al, 1996; Muzio et al., 1996). However, the mechanism by which the cysteineactive-site protease cascade is activated during apoptosis following signals such as growth factor deprivation is not known.

The bone marrow cell line, BAF3, is dependent on IL-3 for growth in culture and enters apoptosis on IL-3 removal (Rodriguez-Tarduchy et al, 1990). DNA fragmentation and loss of cell viability occur when IL-3 is removed, but only after a delay of at least $8 \mathrm{~h}$ (Rodriguez-Tarduchy et al, 1990). New gene expression is not required for entry into apoptosis and IL-3 can rescue cells when readded close to the time of fragmentation (Rodriguez-Tarduchy et al, 1990; Collins et al, 1992). Apoptosis following factor removal is inhibited by over-expression of the bcl-2 protein, which allows cell survival, but does not promote cell growth (Marvel et al, 1993). Bcl-2 protein is associated with a variety of intracellular membranes and homodimerises and heterodimerises with a family of bcl-2 related proteins to inhibit apoptosis (Korsmeyer, 1995). Apoptosis following IL-3 removal requires cysteine-active-site protease activation, which is prevented in BAF-3 cells overexpressing bcl-2 (Furlong et al, 1997).

It has been proposed that mitochondrial disfunction can be a trigger of the late stages of apoptosis, since isolated mitochondria can induce apoptotic events in nuclei (Marchetti et al, 1996). Furthermore, bongkrekic acid (BA), which is a ligand for the adenine nucleotide translocator (ANT) and blocks mitochondrial permeability transition (Zoratti and Szabo, 1995), can be used to inhibit apoptosis induced by many agents whose primary site of action is mitochondria (Zamzami et al, 1996; Marchetti et al, 1996). In order to determine whether mitochodrial disfunction could trigger apoptosis in growth factor dependent cells, BAF3 cells were treated with the potassium ionophore valinomycin. Here we report that valinomycin induces apoptosis by triggering mitochondrial permeability 


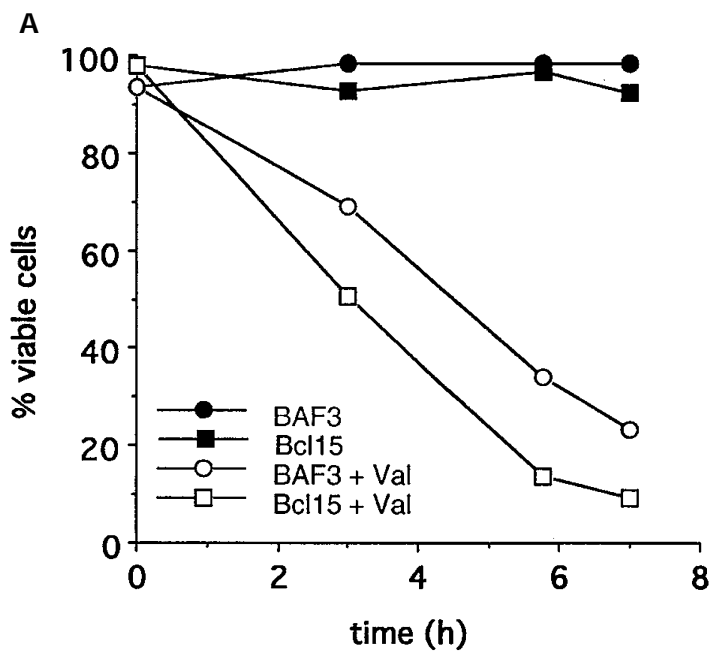

B

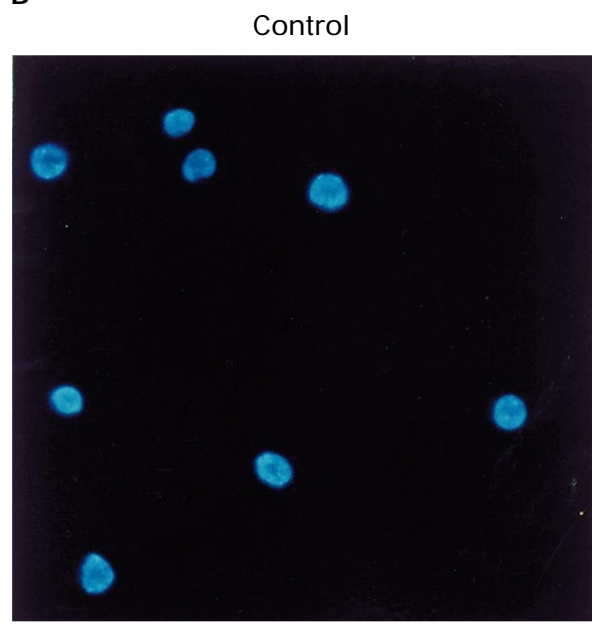

C
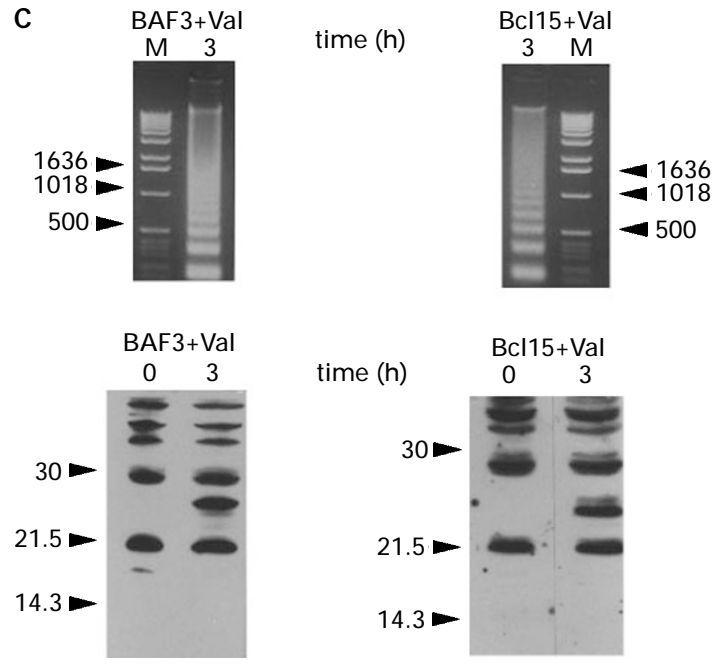

BAF3

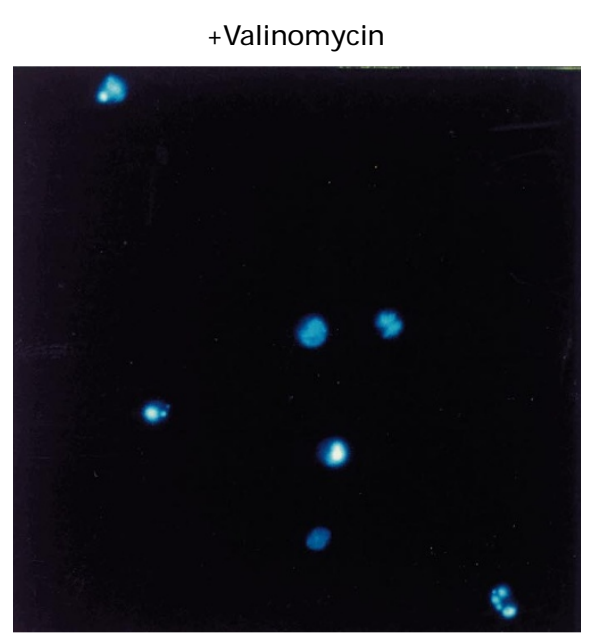

D
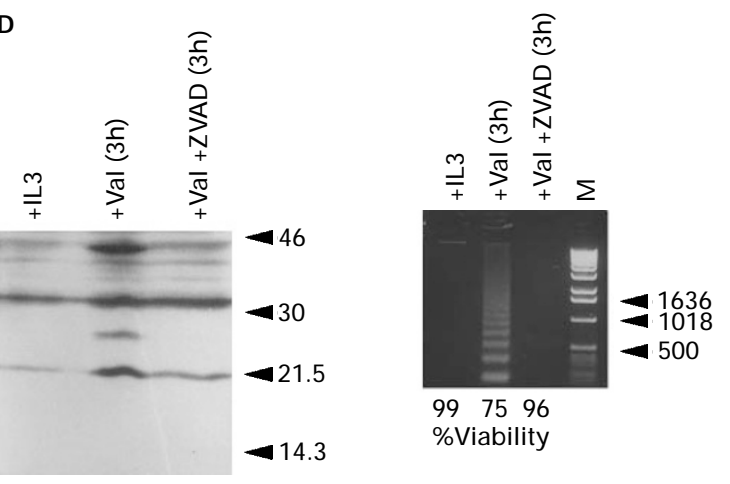

Figure 1 Valinomycin induces apoptosis by activating cysteine-active-site proteases. (A) BAF3 and Bcl-15 cells were incubated with $10 \mu \mathrm{M}$ valinomycin as indicated, for the time shown, in the presence of IL-3. Samples of at least 100 cells were assessed for viability by trypan blue staining. Data are representative of three separate experiments. (B) BAF3 cells, untreated or after $3 \mathrm{~h}$ treatment with $10 \mu \mathrm{M}$ valinomycin in the presence of IL-3, were stained with Hoechst 33342 and visualised by fluorescence microscopy using a $\times 63$ objective. (C) Cell extracts were prepared from BAF3 or Bcl-15 cells, either untreated (0) or incubated with $10 \mu \mathrm{M}$ valinomycin for $3 \mathrm{~h}$ in the presence of IL-3 (3). They were then analyzed for DNA fragmentation (size markers in bp), or PARP cleavage (size markers in $\mathrm{kDa}$ ), as described in Materials and Methods. (D) BAF3 cells were incubated for $1 \mathrm{~h}$ with $200 \mu \mathrm{M}$ ZVAD, prior to treatment with $10 \mu \mathrm{M}$ valinomycin for $3 \mathrm{~h}$, in the presence of IL-3. Samples were then analyzed for PARP cleavage, DNA fragmentation and cell viability 
transition, leading to cytoplasmic acidification, cysteineactive-site protease activation and DNA fragmentation.

\section{Results}

Viability of BAF3 cells and in their derivative $\mathrm{Bcl}-15$, which overexpress $\mathrm{Bcl}-2$, after treatment with valinomycin was determined by trypan blue exclusion. Figure $1 \mathrm{~A}$ shows that in the presence of IL-3, valinomycin induced a decrease in viability of both cell lines. Loss of viability was rapid, with most cells being permeable to trypan blue after $7 \mathrm{~h}$. This time course was not changed by treatment with valinomycin in the absence of IL-3 (data not shown). In order to determine whether this loss of viability was due to apoptosis, the nuclei of valinomycin-treated cells were stained with Hoescht 33342. Figure $1 \mathrm{~B}$ shows that pycnotic nuclei, with the condensed chromatin characteristic of apoptotic nuclei, were observed $3 \mathrm{~h}$ after valinomycin addition. Valinomycin also triggered biochemical changes characteristic of apoptosis. Figure 1C shows that PARP cleavage as a result of cysteine-active-site protease activation was observed in both BAF3 and $\mathrm{Bcl}-15$ cells after valinomycin treatment. Valinomycin treated BAF3 and $\mathrm{Bcl}-15$ cells also showed DNA fragmentation to internucleosome fragments (Figure 1C). Valinomycin has also been shown to induce apoptosis in T-cell lines CTLL-2 and EL-4 (Duke et al, 1994). Here we demonstrate that induction of apoptosis by valinomycin could not be inhibited by the presence of IL-3 or by Bcl-2 overexpression.

The cell permeable inhibitor of cysteine-active-site proteases, ZVAD, was used to determine the effect of protease inhibition on events induced by valinomycin. Prior to treatment with valinomycin, cells were incubated for $2 \mathrm{~h}$ in the presence of $200 \mu \mathrm{M}$ ZVAD. Figure 1D shows that, in the presence $200 \mu \mathrm{M} Z \mathrm{ZVAD}$, the PARP cleavage product was not detected and thus cysteine-active-site protease activity was inhibited. Figure 1D also shows that, under these conditions of inhibited protease activity, chromatin fragmentation and loss of viability induced by valinomycin were also inhibited. In the absence of ZVAD, chromatin laddering was induced after $3 \mathrm{~h}$ of valinomycin treatment. In the presence of ZVAD chromatin laddering was blocked and only $75 \%$ of valinomycin-treated cells

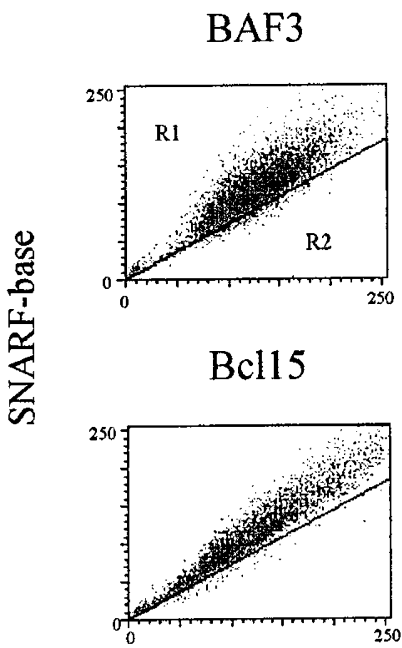

BAF3 $+\mathrm{Val}$

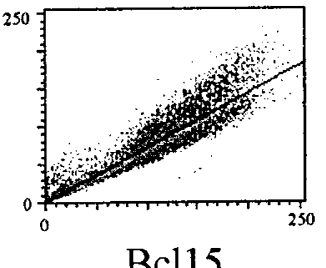

Bcl15

+ Val

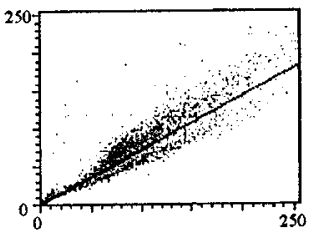

\section{SNARF-acid}

\section{B}

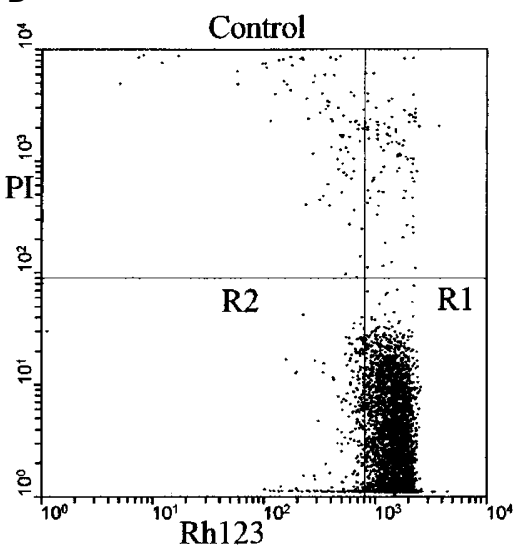

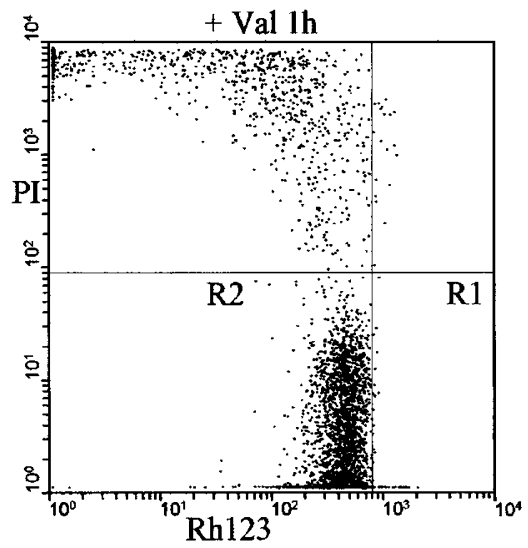

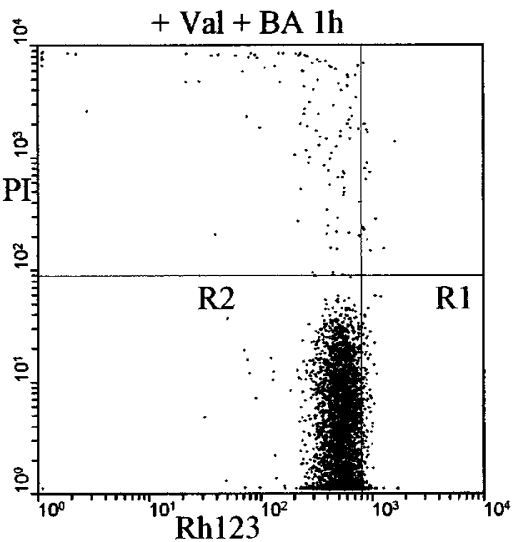


remained viable compared to almost $100 \%$ viability in ZVAD-inhibited cells. Cells remained over $90 \%$ viable for up to $10 \mathrm{~h}$ in the presence of ZVAD and valinomycin (data not shown). Therefore, cysteine-active-site protease activation was necessary for induction of apoptosis by valinomycin.

We have previously reported that a decrease in intracellular $\mathrm{pH}$ precedes cysteine-active-site protease activation in BAF3 cells upon IL-3 removal and that decreasing intracellular $\mathrm{pH}$ with the ionophore nigericin triggers cysteine-active-site protease activation and apoptosis (Furlong et al, 1997). In order to examine whether valinomycin treatment also caused intracellular acidification, cells treated with valinomycin were labelled with SNARF-1$\mathrm{AM}$ and displayed on a two-dimensional scatter plot. Figure $2 \mathrm{~A}$ shows that after a 30 min incubation with valinomycin in the presence of IL-3, $50.4 \%$ of BAF3 cells appeared in a low $\mathrm{pH}$ population R2. Cells in $\mathrm{R} 2$ represented those whose intracellular $\mathrm{pH}$ had dropped to 0.4 units below that in control cells ( $\mathrm{pH}$ 7.3). This rapid intracellular acidification was also observed in the $\mathrm{Bcl}-2$ overexpressors $\mathrm{Bcl}-15$. After $30 \mathrm{~min}, 42.2 \%$ of $\mathrm{Bcl}-15$ cells, treated identically, had decreased intracellular $\mathrm{pH}$ (Figure 2A).

One site of action of valinomycin is mitochondria, where $\mathrm{K}^{+}$transport through the inner mitochondrial membrane by valinomycin has the effect of decreasing $\Delta \Psi$ (Sharpe et al,

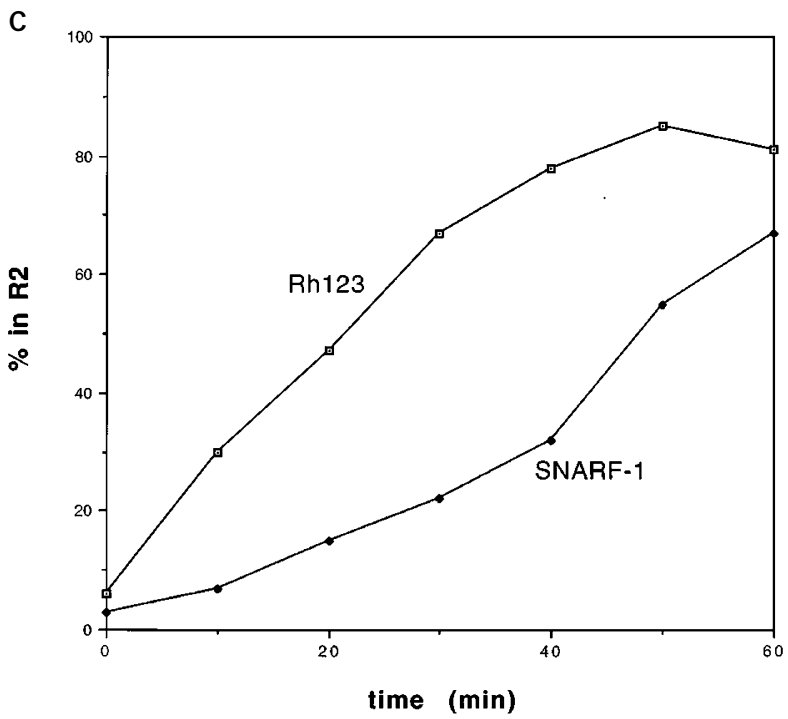

D

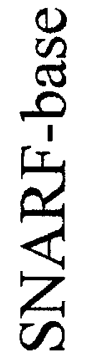

Control

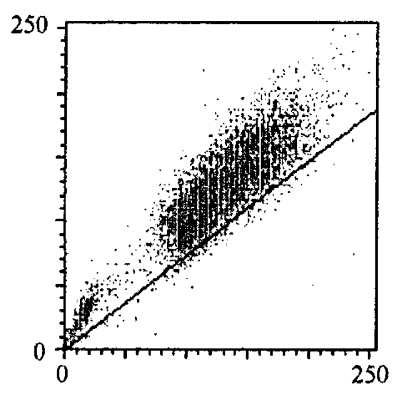

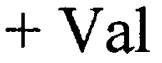

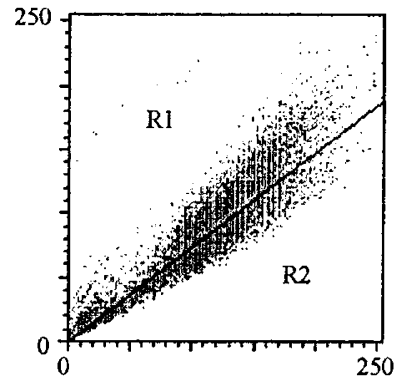

$+\mathrm{Val}+\mathrm{ZVAD}$

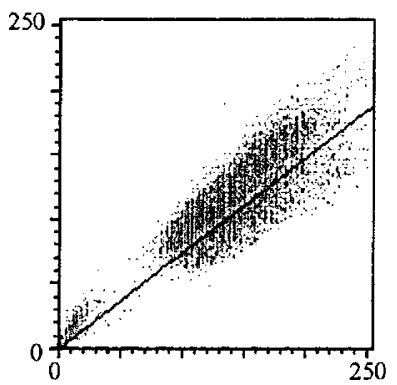

\section{SNARF-acid}

Figure 2 Valinomycin induces rapid cytoplasmic acidification. (A) BAF3 or Bcl-15 cells were incubated for 30 min with $25 \mu \mathrm{M}$ valinomycin in the presence of IL-3, labelled with SNARF-1-AM as described in Materials and Methods, then analyzed by FACScan and displayed on a two dimensional scatter plot. Representative plots from one of three separate experiments are shown. Comparison with a callibration curve, described in Materials and Methods, demonstrated that cells in R1, defined as that which contains $90 \%$ of untreated cells, had an average intracellular pH of $7.30 \pm 0.06$ (mean \pm S.E., three experiments) and cells in R2 had an average $\mathrm{pH}$ of $6.90 \pm 0.03$. In the presence of valinomycin $50.4 \pm 5.0 \%$ of BAF3 cells and $42.2 \pm 21.3 \%$ of Bcl-15 cells were in R2. (B) BAF3 cells were treated for $1 \mathrm{~h}$ with $25 \mu \mathrm{M}$ valinomycin and $100 \mu \mathrm{M}$ bongkrekic acid (BA) and in the presence of IL-3, then stained with Rh123 and PI, analyzed by FACScan and displayed on a two dimensional scatter plot, as described in Materials and Methods. R1 is defined to contain $90 \%$ of untreated cells. (C) Change in SNARF and Rh123 fluorescence after BAF3 cells were treated for the time shown with $25 \mu \mathrm{M}$ valinomycin in the presence of IL-3. (D) BAF3 cells were incubated for $1 \mathrm{~h}$ with $200 \mu \mathrm{M}$ ZVAD, prior to treatment with $25 \mu \mathrm{M}$ valinomycin for $30 \mathrm{~min}$, in the presence of IL-3. In the experiment shown, $52 \%$ of cells were in R2 after treatment with valinomycin and $22 \%$ were in $\mathrm{R} 2$ after treatment with valinomycin in the presence of ZVAD 
1995). $\Delta \Psi$ in whole cells can be measured by staining with rhodamine 123, which diffuses into mitochondria where its retention depends on $\Delta \Psi$ (Kinally et al, 1978). Figure 2B shows that a population of BAF3 cells with decreased rhodamine 123 fluorescence could be detected after valinomycin treatment. Bongkrekic acid (BA), which is a ligand for the adenine nucleotide translocator (ANT) and blocks mitochondrial permeability transition (PT) (Zoratti and Szabo, 1995), did not inhibit accumulation of cells with decreased rhodamine 123 fluorescence (Figure 2B). This suggested that the primary action of valinomycin was to decrease $\Delta \Psi$. Figure $2 \mathrm{C}$ further supports this idea by showing that the population of cells with decreased $\mathrm{pH}$ appeared after those with decreased $\Delta \Psi$. It has previously been reported, in apoptosis induced by anti-Fas antibody, that cysteine-active-site protease activation precedes intracellular acidification (Meisenholder et al, 1996). However, we have demonstrated that intracellular acidification precedes cysteine-active-site protease activation in BAF3 cells deprived of IL-3 (Furlong et al, 1997). Likewise, when apoptosis was induced by valinomycin, inhibition of cysteine-active-site protease activation by ZVAD did not prevent acidification (Figure 2D). These data support the idea that a rapid decrease in $\Delta \Psi$ followed by a $\mathrm{pH}$ decrease was stimulated by valinomycin, which preceded the irreversible onset of apoptosis.

Disruption of $\Delta \Psi$ can be responsible for mitochondrial PT, which is the opening of protaceous pores in the inner mitochondrial membrane allowing free distributions of solutes between matrix and cytosol (Bernardi et al, 1993). It has been proposed that PT is a critical event in activating late stages of apoptosis since isolated mitochondria undergoing PT can induce apoptotic events in nuclei in a cell free system (Marchetti et al, 1996). PT can only be directly measured in vitro, by swelling of permeable mitochondria in hypotonic buffer. However, in whole cells, bongkrekic acid (BA), which is a ligand for the mitochondrial adenine nucleotide translocator (ANT) responsible for the PT (Zoratti and Szabo, 1995), can be used to prevent the PT and inhibit apoptosis induced by many agents whose primary site of action is mitochondria (Zamzami et al, 1996; Marchetti et al, 1996). Cells were therefore treated with valinomcyin in the absence or presence of BA then incubated with SNARF-1-AM to determine the effect of $\mathrm{BA}$ inhibition on intracellular $\mathrm{pH}$ changes. Figure $3 \mathrm{~A}$ shows that intracellular $\mathrm{pH}$ was not affected by incubation of cells in $100 \mu \mathrm{M}$ BA. However, after valinomycin treatment, the appearance of cells in the low $\mathrm{pH}$ population $\mathrm{R} 2$ is effectively blocked by the presence of BA. In the presence of valinomycin alone, $53.6 \%$ of cells were in R2 whereas only $5.6 \%$ of BA treated cells had an intracellular $\mathrm{pH}$ below control cells. Figure $3 \mathrm{~B}$ and $\mathrm{C}$ shows that in the presence of $100 \mu \mathrm{M}$ $B A$, the DNA fragmentation and loss of cell viability induced by valinomycin were also substantially inhibited. BA alone had no effect on cell viability (data not shown), however after $6 \mathrm{~h}$ treatment with valinomycin, viability was reduced to $20 \%$ but maintained at $70 \%$ by the addition of BA. This suggests that the effect of valinomycin following its decrease of $\Delta \Psi$ is to trigger the mitochondrial $\mathrm{PT}$, which then leads to acidification and the subsequent stages of apoptosis.

\section{Discussion}

A drop in intracellular $\mathrm{pH}$ can be induced in BAF3 cells by treatment with the potassium ionophore valinomycin. Following this acidification, cells die by apoptosis displaying pycnotic nuclei, cysteine-active-site protease activation and chromatin fragmentation. These effects are rapid and occur in the presence of IL-3 or Bcl-2 overexpression. Acidification and apoptosis induced by valinomycin are blocked by bongkrekic acid (BA), an inhibitor of the mitochondrial permeability transition (PT).

Valinomycin, an antibiotic ionophore produced by Streptomycetes, is a cyclic poly-peptide-like molecule whose folded conformation forms an inner cavity that can accommodate $\mathrm{K}^{+}$but not other ions. Since the outer surface is hydrophobic, the molecule is soluble in lipid bilayers and can diffuse across membranes. When added to intact cells, it can transport $\mathrm{K}^{+}$ions both outwards across the plasma membrane and inwards across the mitochondrial inner membrane, driven by $\mathrm{K}^{+}$gradients. By collapsing the $\mathrm{K}^{+}$gradient across the mitochondrial inner membrane, valinomycin decreases $\Delta \Psi$ (the mitochondrial membrane potential). A decrease in $\Delta \Psi$ occurs during apoptosis in dexamethasone and etoposide-treated $\mathrm{T}$ and $\mathrm{B}$ lymphocytes (Zamzami et al, 1996), during positive and negative selection (Zamzami et al, 1995), in rat neurones deprived of NGF (Deckwerth and Johnson, 1993) and TNF-stimulated U937 cells (Cossarizza et al, 1995). A decrease in rhodamine 123 fluorescence, a measurement of $\Delta \Psi$, was also detected after $10 \mathrm{~min}$ in $30 \%$ of BAF3 cells treated with valinomycin.

The next effect of valinomycin was intracellular acidification, detectable in $30 \%$ of cells after 40 min, which we have previously demonstrated induces cysteine-active-site protease activation and apoptosis in BAF3 cells (Furlong et al, 1997). BA inhibited this decrease in intracellular $\mathrm{pH}$ induced by valinomycin but not the decrease in rhodamine 123 fluorescence. This suggests that the effect of valinomycin on $\Delta \Psi$ can trigger PT (Bernardi et al, 1993), which then leads to acidification. Isolated mitochondria over-expressing $\mathrm{Bcl}-2$ have been shown to be inhibited in the PT induced by atractyloside which binds the mitochondrial adenine nucleotide translocator (ANT). However, Bcl-2 could not inhibit the effect of some other PT inducers including calcium and diamide (Marchetti et al, 1996). This paralleled the ability of $\mathrm{Bcl}-2$ to inhibit apoptosis induced by atractyloside, but not calcium or diamide, in $\mathrm{T}$ cell hybridomas (Zamzami et al, 1996). Likewise, Bcl-2 overexpression could not inhibit acidification induced by valinomycin.

How PT induced by valinomycin causes a drop in intracellular $\mathrm{pH}$ remains to be determined. We have previously described acidification induced by IL-3 removal, etoposide treatment, or the ionophore nigericin (Furlong et al, 1997). However, BA had no effect on acidification or apoptosis following these treatments ((Furlong et al, 1997) and data not shown). This suggests that acidification can 
A

\section{Control}
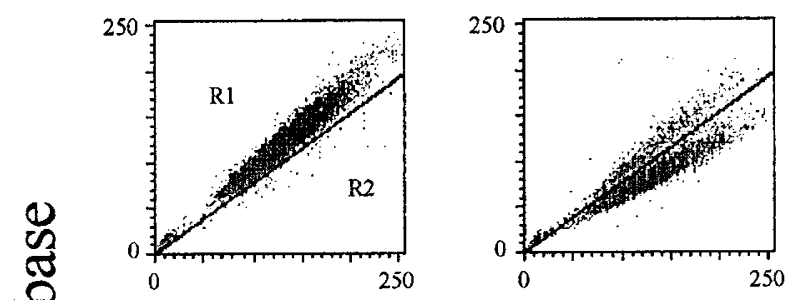

BA

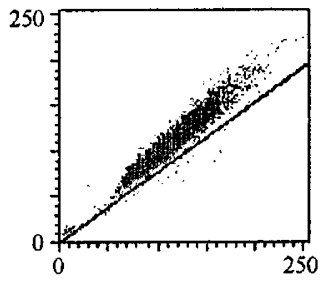

$+\mathrm{Val}$

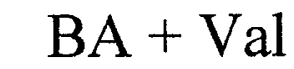

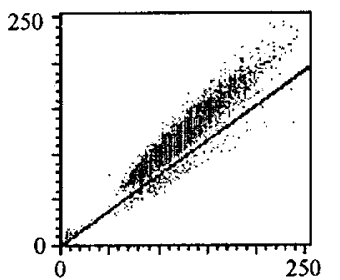

SNARF-acid

B

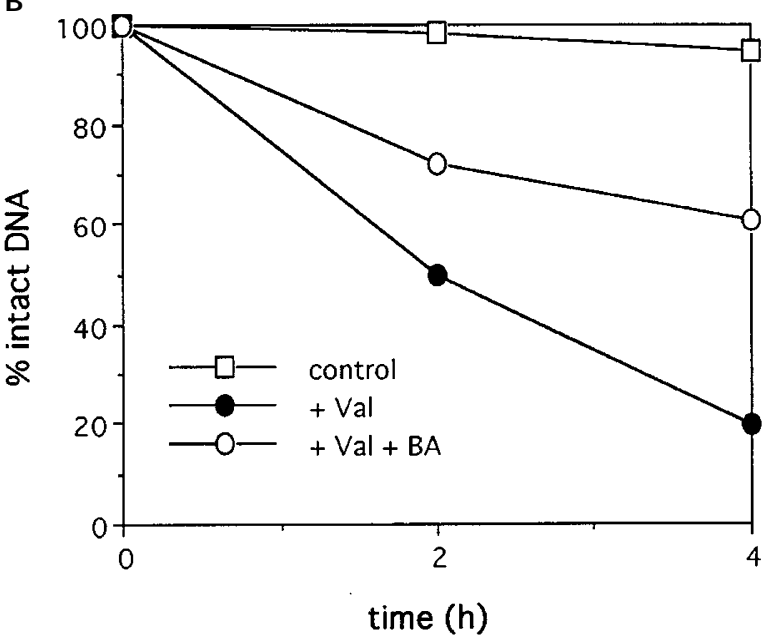

C

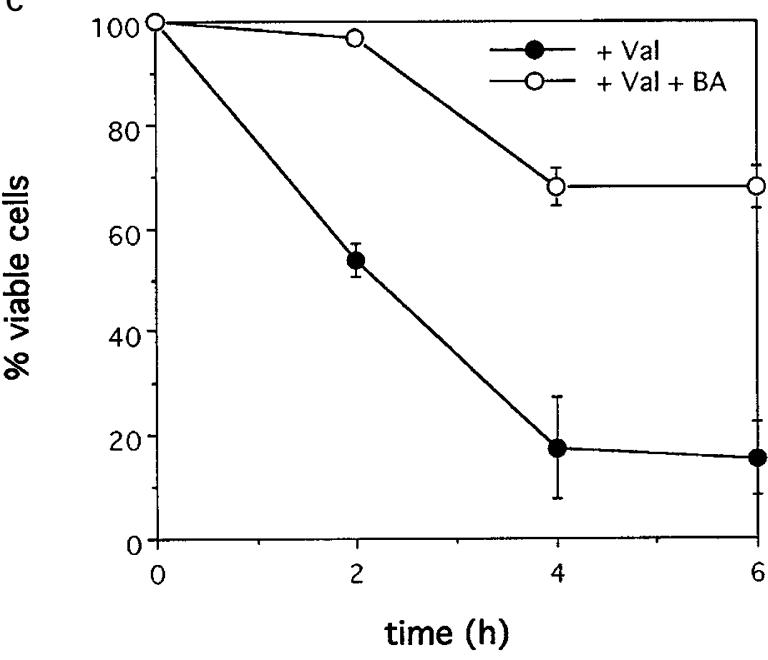

be induced by a number of pathways and that it provides a central stimulus for cysteine-active-site protease activation which in turn stimulates DNA fragmentation.

\section{Materials and Methods}

\section{Cell culture}

BAF3 cells (obtained from Dr Ronald Palacios, Basel Institute for Immunology) (Palacios, 1985) were maintained in Dulbecco's modified Eagle's medium (DMEM) (Gibco Europe) containing $10 \%$ foetal calf serum (FCS) (Gibco Europe) and 5\% cell-conditioned medium from the IL-3-producing cell line Wehi-3B. This was used as a source of IL-3 throughout. To remove IL-3, cells were washed twice in DMEM. BAF3 cells expressing human $\mathrm{Bcl}-2$ (clone $\mathrm{Bcl}-15$ ) were previously described (Marvel et al, 1993). BAF3 and Bcl-15 cells were grown at a density of $5 \times 10^{4}$ to $5 \times 10^{5}$ cells $/ \mathrm{ml}$ at $37^{\circ} \mathrm{C}$ in a humidified atmosphere with $10 \% \mathrm{CO}_{2}$. Valinomycin was obtained from Sigma and ZVAD from Enzyme Systems Products, Dublin, USA. Bongkrekic acid was the gift of Professor J.A. Duine (Department of Microbiology/ Enzymology, Delft University of Technology, Netherlands).

\section{Cell counting and morphology}

Cell numbers were determined by counting on a haemocytometer. Cell viability was determined by staining cells with trypan blue and counting the percentage of cells excluding stain. To examine nuclear morphology, cells were pelleted and resuspended at $5 \times 10^{6} \mathrm{cells} / \mathrm{ml}$ in phosphate buffered saline (PBS) $+2.5 \mu \mathrm{g} / \mathrm{ml} \mathrm{Hoechst} 33342$ (Sigma) before examination by fluorescence microscopy (UV-light source plus filter) using a Zeiss Axioskop microscope.

\section{Intracellular $\mathrm{pH}$ and $\Delta \Psi$ measurements by FACScan}

Intracellular $\mathrm{pH}$ measurements were performed according to the method detailed in (Rabinovitch, 1990). Briefly, for the final 15 min of each experiment, $1 \times 10^{6}$ cells were incubated with $20 \mu \mathrm{M}$ CarboxySNARF-1-AM Acetate (Calbiochem) in $200 \mu \mathrm{l}$ complete medium at $37^{\circ} \mathrm{C}$ in a humidified $10 \% \mathrm{CO}_{2}$ atmosphere. Loaded cells were then washed in Electrolyte Solution (5 mM Pipes/Tris pH 7.2, $140 \mathrm{mM}$ $\mathrm{NaCl}, 5 \mathrm{mM} \mathrm{KCl}, 1 \mathrm{mM} \mathrm{MgCl}$, $1 \mathrm{mM} \mathrm{CaCl}, 10 \mathrm{mM}$ D-Glucose), resuspended in fresh electrolyte solution and incubated at $37^{\circ} \mathrm{C}$ for $5 \mathrm{~min}$ before analysis on FACScan. Intracellular carboxy-SNARF-1 was excited at $488 \mathrm{nM}$ and emission measured at 575 and $670 \mathrm{nM}$ using linear amplifiers. Intracellular $\mathrm{pH}$ values were determined by

Figure 3 Bongkrekic acid inhibits apoptosis induced by valinomycin. (A) BAF3 cells were pre-incubated for $1 \mathrm{~h}$ with $100 \mu \mathrm{M}$ bongkrekic acid (BA), before treatment for $30 \mathrm{~min}$ with $25 \mu \mathrm{M}$ valinomycin in the presence of BA and IL-3, as indicated. SNARF-1 labelled cells were then analyzed by FACScan and displayed on a two dimensional scatter plot. In the presence of valinomycin $53.6 \pm 5.5 \%$ (mean \pm S.E., three experiments) of cells were in $\mathrm{R} 2$, with $\mathrm{BA}$ alone $4.5 \pm 3.1 \%$ were in R2 and with valinomycin+BA $5.6 \pm 3.1 \%$ were in R2. (B) ${ }^{3} \mathrm{H}$-thymidine labelled BAF3 cells were pre-incubated for $1 \mathrm{~h}$ with $100 \mu \mathrm{M}$ bongkrekic acid (BA), before treatment with $10 \mu \mathrm{M}$ valinomycin in the presence of BA and IL-3, as indicated, for the time shown. Release of DNA was measured as described in Materials and Methods. (C) BAF3 cells were pre-incubated for $1 \mathrm{~h}$ with $100 \mu \mathrm{M}$ bongkrekic acid (BA), before treatment with $10 \mu \mathrm{M}$ valinomycin in the presence of BA and IL-3, as indicated, for the time shown. Viability was assessed by trypan blue staining and counting at least 100 cells, each point represents the mean \pm S.E. of two experiments 
comparing mean $575 / 670 \mathrm{nM}$ fluorescence ratio values to a calibration curve constructed by incubating carboxy-SNARF-1-loaded BAF3 cells in a range of $\mathrm{pH}$ buffers in the presence of the ionophore nigericin (Sigma) at $2 \mu \mathrm{g} / \mathrm{ml}$. pH calibration buffers were made by mixing $20 \mathrm{mM}$ PIPES or $20 \mathrm{mM}$ Tris in $130 \mathrm{mM} \mathrm{KCl}, 20 \mathrm{mM} \mathrm{NaCl}, 1 \mathrm{mM} \mathrm{MgCl}_{2}$, $1 \mathrm{mM} \mathrm{CaCl}_{2}, 10 \mathrm{mM} \mathrm{D}$-Glucose to give a range of $\mathrm{pH} 5-8$ at $37^{\circ} \mathrm{C}$. To represent the fluorescence of each SNARF-1 labelled cell, a 2 dimensional dot plot with $575 \mathrm{nM}$ fluorescence on the x-axis (SNARFacid) and $670 \mathrm{nM}$ fluorescence on the $y$-axis (SNARF-base) was displayed. On this plot, the distance of each cell from the origin is directly proportional to the amount of SNARF-1 loaded in the cell and the ratio of $575 / 670 \mathrm{nM}$ fluorescence is a measure of intracellular $\mathrm{pH}$.

$\Delta \Psi$ was measured by incubating $4 \times 10^{5}$ cells with $100 \mathrm{nM}$ rhodamine 123 (Sigma) in $2 \mathrm{ml}$ complete medium at $37^{\circ} \mathrm{C}$ in a humidified $10 \% \mathrm{CO}_{2}$ atmosphere, for the final $10 \mathrm{~min}$ of each experiment. Cells were pelleted at $4^{\circ} \mathrm{C}$ then resuspended in $1 \mathrm{ml}$ ice cold PBS containing $1 \mu \mathrm{g} / \mathrm{ml}$ propidium iodide, before analysis on FACScan. A 2-dimensional dot plot with rhodamine 123 fluorescence on the $x$-axis and propidium iodide fluorescence on the $y$-axis was displayed.

\section{Chromatin fragmentation}

In order to isolate apoptotic DNA fragments from treated cells, the method of Herrmann et al was followed (Herrmann et al, 1994). $10^{6}$ cells were washed in PBS and pelleted by centrifugation. Cell pellets were then lysed for $10 \mathrm{~s}$ with $50 \mu \mathrm{l}$ DNA lysis buffer (1\% NP40 in $20 \mathrm{mM}$ EDTA, $50 \mathrm{mM}$ Tris- $\mathrm{HCl} \mathrm{pH} \mathrm{7.5).} \mathrm{After} \mathrm{centrifugation} \mathrm{at}$ $13000 \mathrm{~g}$ for $20 \mathrm{~s}$, the supernatant was removed and extraction from the pellet repeated. Apoptotic DNA fragments were recovered from the combined supernatants by adding SDS to $1 \%$ and treating with $5 \mathrm{mg} /$ $\mathrm{ml}$ RNaseA for $2 \mathrm{~h}$ at $56^{\circ} \mathrm{C}$ followed by digestion with proteinase $\mathrm{K}$ $(2.5 \mathrm{mg} / \mathrm{ml})$ for $2 \mathrm{~h}$ at $37^{\circ} \mathrm{C}$. DNA was precipitated with $0.5 \mathrm{vol} 10 \mathrm{M}$ ammonium acetate and $2.5 \mathrm{vol}$ ethanol, dissolved in gel loading buffer and separated by electrophoresis in $1.2 \%$ agarose gels. $1 \mu \mathrm{g}$ of commercial $\lambda$ DNA ladder (Gibco BRL) was run in parallel.

For measurement of chromatin fragmentation in intact cells by $\left[{ }^{3} \mathrm{H}\right]$ thymidine release, cells $\left(2 \times 10^{5}\right.$ cells $\left./ \mathrm{ml}\right)$ were incubated overnight with $1 \mu \mathrm{Ci} / \mathrm{ml}$ of $\left[{ }^{3} \mathrm{H}\right]$ thymidine $(20 \mathrm{Ci} / \mathrm{mmol}$ Amersham International) then washed twice before incubation for the time shown. Cells were harvested using a Dynatech cell harvester (Dynatech Labs Ltd. Sussex, UK). ${ }^{3} \mathrm{H}$ counts were measured by scintillation counting. Chromatin fragmentation was calculated as retained ${ }^{3} \mathrm{H}$-labelled DNA as a percentage of total ( $\mathrm{t}=0$ counts).

\section{Analysis of PARP cleavage}

Cells $\left(1 \times 10^{6}\right.$ per track) were lysed in gel sample buffer, boiled and sonicated before size fractionation of proteins on $12.5 \%$ SDS-PAGE. Proteins were transferred to nitro-cellulose membranes by electroblotting, blocked and incubated for $2 \mathrm{~h}$ at room temperature with the anti-PARP antibody anti-FII (gift of Dr. G. de Murcia (CNRS Illkirch, Strasbourg) diluted 1:1000 in blocking buffer. Anti-FII is a polyclonal rabbit serum raised against a synthetic polypeptide corresponding to the second zinc finger of the DNA binding domain of human PARP that detects a $25 \mathrm{kDa}$ fragment after PARP cleavage. HRP-conjugated goat anti-rabbit and ECL were used for detection.

\section{Acknowledgements}

This work was supported by the Cancer Research Campaign, UK and the CSIC, Spain.

\section{References}

Bernardi P, Veronese P and Petronilli V (1993) Modulation of the mitochondrial cyclosporin A-sensitive permeability transition pore. J. Biol. Chem. 268: 1005-1010

Boldin MP, Goncharov TM, Goltsev YV and Wallach D (1996) Involvement of MACH a novel MORT1/FADD-Interacting protease in Fas/APO-1- and TNF receptorinduced cell death. Cell 85: 803-815

Camita SG, Majima K and Maeda S (1993) Identification and characterisation of the p35 gene of Bombyx mori nuclear polyhedrosis virus that prevents virus-induced apoptosis. J. Virol. 67: 455-463

Casciola-Rosen LA, Miller DK, Anhalt GJ and Rosen A (1994) Specific cleavage of the $70-\mathrm{kDa}$ protein component of the $\mathrm{U} 1$ small nuclear ribonucleoprotein is a characteristic biochemical feature of apoptotic cell death. J. Biol. Chem. 269: 30757-30760

Chow SC, Weis M, Kass GE, Holmstrom TH, Eriksson JE and Orrenius S (1995) Involvement of multiple proteases during Fas-mediated apoptosis in $\mathrm{T}$ lymphocytes. FEBS Lett. 364: 134-138

Collins MK, Marvel J, Malde P and Lopez-Rivas A (1992) Interleukin 3 protects murine bone marrow cells from apoptosis induced by DNA damaging agents. J. Exp. Med. 176: 1043-1051

Collins MKL, Perkins GR, Rodriguez-Tarduchy G, Nieto MA and Lopez-Rivas A (1994) Growth factors as survival factors: regulation of apoptosis. BioEssays 16: $133-138$

Cossarizza A, Francheschi C, Monti D, Salvioli S, Bellesia E, Rivabene R, Biondo L, Rainaldi G, Tinari A and Malorni W (1995) Protective effect of $\mathrm{N}$-acetylcysteine in tumor necrosis factor-alpha-induced apoptosis in U937 cells: the role of mitochondria. Exp. Cell Res. 220: 232-240

Deckwerth TL and Johnson EM (1993) Temporal analysis of events associated with apoptosis of sympathetic neurons deprived of nerve growth factor. J. Biol. Chem. 123: $1207-1222$

Duke RC, Witter RZ, Young PB and Ojcius DM (1994) Cytolysis mediated by ionophores and pore-forming agents: role of intracellular calcium in apoptosis. FASEB J. 8: $237-246$

Enari M, Hase A and Nagata S (1995a) Apoptosis by a cytosolic extract from Fasactivated cells. EMBO J. 14:5201-5208

Enari M, Hug H and Nagata S (1995b) Involvement of an ICE-like protease in Fasmediated apoptosis. Nature 375: 78-81

Enari M, Talanian RV, Wong WW and Nagata S (1996) Sequential activation of ICElike and CPP32-like proteases during Fas-mediated apoptosis. Nature 380: $723-726$

Fearnhead HO, Dinsdale D and Cohen GM (1995) An interleukin-1beta-converting enzyme-like protease is a common mediator of apoptosis in thymocytes. FEBS Lett. 375: 283-288

Furlong I, Ascaso R, Lopez-Rivas A and Collins M (1997) Intracellular acidification induces apoptosis by stimulating ICE-like protease activity. J. Cell Sci. 110: $653-661$

Gagliardini V, Fernandez PA, Lee RKK, Drexier HCA, Rotello RJ, Fishman MC and Yuan J (1994) Prevention of vertebrate neuronal death by the crmA gene. Science 263: 826-828

Herrmann M, Lorenz HM, Voll R, Grunke M, Woith W and Kalden JR (1994) A rapid and simple method for the isolation of apoptotic DNA fragments. Nucleic Acids Res. 22: 5506-5507

Jacobson MD, Weil M and Raff MC (1996) Role of Ced-3/ICE-family proteases in staurosporine-induced programmed cell death. J. Cell Biol. 133: 1041-1051

Kaufmann SH, Desnoyers S, Ottaviano Y, Davidson NE and Poirier GG (1993) Specific proteolytic cleavage of poly(ADP-ribose) polymerase: an early marker of chemotherapy-induced apoptosis. Cancer Res. 53: 3976-3985

Kinally LW, Tedeschi H and Maloff BL (1978) Use of dyes to estimate the electrical potential of the mitochondrial membrane. Biochemistry 17: 3419-3428

Korsmeyer SJ (1995) Regulators of cell death. Trends Genet. 11: 101-105

Kumar S and Harvey N (1995) Role of multiple cellular proteases in the execution of programmed cell death. FEBS Lett. 375: 169-173

Lazebnik Y, Cole S, Cooke C, Nelson W and Earnshaw W (1993) Nuclear events of apoptosis in vitro in cell free mitotic extracts: a model system for analysis of the active phase of apoptosis. J. Cell Biol. 123: 7-22

Lazebnik YA, Takahashi A, Moir RD, Goldman RD, Poirier GG, Kaufmann SH and Earnshaw WC (1995) Studies of the lamin proteinase reveal multiple parallel biochemical pathways during apoptotic execution. Proc. Natl. Acad. Sci. USA. 92: $9042-9046$ 
Los M, Van dCM, Penning LC, Schenk H, Westendorp M, Baeuerle PA, Droge W, Krammer PH, Fiers W and Schulze OK (1995) Requirement of an ICE/CED-3 protease for Fas/APO-1 mediated apoptosis. Nature 375: 81-83

Marchetti P, Castedo M, Susin SA, Zamzami N, Hirsch T, Macho A, Haeffner A, Hirsch $F$, Geuskens $M$ and Kroemer $G$ (1996) Mitochondrial permeability transition is a central coordinating event of apoptosis. J. Exp. Med. 184: 1155-1160

Martin S and Green D (1995) Protease activation during apoptosis. Cell 82: 349-352

Martin SJ, Newmeyer DD, Mathias S, Farschon DM, Wang H, Reed JC, Kolesnick RN and Green DR (1995) Cell-free reconstitution of Fas-, UV radiation- and ceramide-induced apoptosis. EMBO J. 14: 5191-5200

Marvel J, Perkins GR, Lopez-Rivas A and Collins MKL (1993) Bcl-2 over-expression in murine bone marrow cells induces refractoriness to interleukin-3 stimulation of proliferation. Oncogene 9: 1117-1122

Meisenholder GW, Martin SJ, Green DR, Nordberg J, Babior BM and Gottlieb RA (1996) Events in Apoptosis (Acidification is downstream of protease activation and bcl-2 protection). J. Biol. Chem. 271: 16260-16262

Muzio M, Chinnaiyan AM, Kischkel FC, O'Rourke K, Shevchenko A, Ni J, Scaffidi C Bretz JD, Zhang M, Gentz R, Mann M, Krammer PH, Peter M and Dixit VM (1996) FLICE, a novel FADD-homologous ICE/CED-3-like protease, is recruited to the CD95 (Fas/APO-1) death-inducing signaling complex. Cell 85: 817-827

Nicholson DW, Ali A, Thornberry NA, Vaillancourt JP, Ding CK, Gallant M, Gareau Y, Griffin PR, Labelle M, Lazebnik YA and et al (1995) Identification and inhibition of the ICE/CED-3 protease necessary for mammalian apoptosis. Nature 376: $37-$ 43

Palacios R and Steinmetz M (1985) IL-3-dependent mouse clones that express B220 surface antigen, contain Ig genes in germ-line configuration, and generate $B$ lymphocytes in vivo. Cell 41: 727-734

Rabinovitch PS and June CH (1990) Flow Cytometry; A Practical Approach. IRL Press pp. 178-185

Rodriguez-Tarduchy G, Collins Mand Lopez-Rivas A (1990) Regulation of apoptosis in interleukin-3-dependent hemopoietic cells by interleukin-3 and calcium ionophores. EMBO J. 9: 2997-3002

Sharpe MA, Wrigglesworth JM, Loewen J and Nicholls $\mathrm{P}$ (1995) Small pH gradients inhibit cytochrome oxidase - implications for $\mathrm{H}^{+}$entry to the binuclear centre. Biochem. Biophys. Res. Comm. 216: 931-938
Solary C, Bertrand R, Kohn KW and Prommier Y (1993) Differential induction of apoptosis in undifferentiated and differentiated HL-60 cells by DNA topoisomerase I and II inhibitors. Blood 81: 1359-1368

Song Q, Lees-Miller S, Kumar S, Zhang N, Chan D, Smith G, Jackson S, Alnemri E, Litwack G, Khanna K and Lavin M (1996) DNA-dependant protein kinase catalytic subunit as a target for an ICE-like protease in apoptosis. EMBO J. 15 : $3238-3246$

Tewari M, Beidler DR and Dixit VM (1995) CrmA-inhibitable cleavage of the $70 \mathrm{kDa}$ protein component of the $\mathrm{U} 1$ small nuclear ribonucleoprotein during Fas- and tumor necrosis factor-induced apoptosis. J. Biol. Chem. 270: 18738-18741

Tewari M and Dixit VM (1995) Fas- and tumor necrosis factor-induced apoptosis is inhibited by the poxvirus crmA gene product. J. Biol. Chem. 270: 3255-3260

Tewari M, Quan LT, O'Rourke K, Desnoyers S, Zeng Z, Beidler DR, Poirier GG, Salvesen GS and Dixit VM (1995) Yama/CPP32 beta, a mammalian homolog of CED-3, is a CrmA-inhibitable protease that cleaves the death substrate poly(ADP-ribose) polymerase. Cell 81: 801-809

Voelkel JC, Entingh AJ, Wold WS, Gooding LR and Laster SM (1995) Activation of intracellular proteases is an early event in TNF-induced apoptosis. J. Immunol. 154: $1707-1716$

Wyllie AH (1980) Glucocorticoid-induced thymocyte apoptosis is associated with endogenous endonuclease activation. Nature 284: $555-556$

Xue D and Horvitz H (1995) Inhibition of the C elegans cell-death protease CED-3 by a CED-3 cleavage site in baculovirus p53 protein. Nature 377: 248-251

Zamzami N, Marchetti P, Castedo M, Zanin C, Vayssiere JL, Petit PX and Kroemer G (1995) Reduction in mitochondrial potential constitutes an early irreversible step of programmed lyphocyte death in vivo. J. Exp. Med. 181: 1661-1672

Zamzami N, Susin S, Marchetti P, Hirsch T, Gomez-Monterrey I, Castedo M and Kroemer G (1996) Mitochondrial control of nuclear apoptosis. J. Exp. Med. 183: $1533-1544$

Zhu H, Fearnhead HO and Cohen GM (1995) An ICE-like protease is a common mediator of apoptosis induced by diverse stimuli in human monocytic THP.1 cells. FEBS Lett. 374: 303-308

Zoratti M and Szabo I (1995) The mitochondrial permeability transition. Biochim. Biophys. Acta 1241: 139-176 